\title{
Fabrication of Dye-Sensitized Solar Cells (DSSC) Using Mg-Doped ZnO as Photoanode and Extract of Rose Myrtle (Rhodomyrtus tomentosa) as Natural Dye
}

\author{
Nurdin Siregar $\mathbb{D}^{1}{ }^{1}$ Motlan, ${ }^{1}$ Jonny Haratua Panggabean, ${ }^{1}$ Makmur Sirait $\mathbb{D},{ }^{1}$ \\ Juniastel Rajagukguk $\left(\mathbb{D},{ }^{1}\right.$ Noto Susanto Gultom $\left(\mathbb{1},{ }^{1}\right.$ and Fedlu Kedir Sabir $\mathbb{1}^{2}$ \\ ${ }^{1}$ Department of Physics, Faculty of Mathematics and Natural Sciences, State University of Medan, Jl. Willem Iskandar Pasar \\ Medan Estate, Medan 20221, Indonesia \\ ${ }^{2}$ Department of Applied Chemistry, School of Applied Natural Science, Adama Science and Technology University, P.O. Box 1888, \\ Adama, Ethiopia
}

Correspondence should be addressed to Nurdin Siregar; siregarnurdin@unimed.ac.id

Received 6 April 2021; Revised 29 June 2021; Accepted 21 August 2021; Published 3 September 2021

Academic Editor: Joaquim Carneiro

Copyright (C) 2021 Nurdin Siregar et al. This is an open access article distributed under the Creative Commons Attribution License, which permits unrestricted use, distribution, and reproduction in any medium, provided the original work is properly cited.

\begin{abstract}
A dye-sensitized solar cell (DSSC) device using Mg-doped $\mathrm{Zn}$ thin films as photoanode and fruit extract of rose myrtle (Rhodomyrtus tomentosa) as the natural dye was investigated. The effect of annealing temperature $\left(400-550^{\circ} \mathrm{C}\right)$ on the films of photoanode was systematically studied using an X-ray diffractometer (XRD), UV-Visible Near Infrared (UV-Vis NIR) Spectrophotometer, scanning electron microscopy (SEM), and energy dispersive spectroscopy (EDS). XRD confirm that all sample has the wurtzite hexagonal with crystallite size of $25 \mathrm{~nm}$. The SEM images reveal particles on the surface of the Mgdoped $\mathrm{ZnO}$ thin film of irregular shapes. Increasing the annealing temperature leads to a larger particle size and slightly increases bandgap energy. The dye sensitizer of extracted rose myrtle (Rhodomyrtus tomentosa) has a strong absorption at the visible light region. The maximum efficiency of the DSSC device is $3.53 \%$ with $\mathrm{Mg}-\mathrm{ZnO}$ photoanode annealed at $500^{\circ} \mathrm{C}$.
\end{abstract}

\section{Introduction}

The demands for renewable energy continually increase every year due to its eco-friendliness. Solar cells have been well known as a device to convert solar energy to electricity for decades. However, conventional solar cells are still high priced due to complicated fabrication process and expensiveness of raw materials. Dye-sensitized solar cell (DSSC) is one of the most promising solar cell types to produce renewable energy with a low-cost material and simple fabrication process [1-3]. After irradiation, the dye sensitizer harvests light and causes an electron to promote the conduction band leaving a hole in the valence band. There are numerous pigments of plant leaves, fruits, and flowers that have the potential to be utilized in DSSC. The variety of pigments with different absorption wavelengths and degrees of absorptivity in the UV-visible spectrum can cause different performances of
DSSC. The molecules of the dye can be anchored into the surface areas of the semiconductor to form Lewis acid-base types of interaction to enhance electron transfer from HOMO of the dye molecule (pigment) to the conduction band of the semiconductor (anode) [4-7].

Zinc oxide $(\mathrm{ZnO})$ semiconductor plays an important role as a photoanode to improve the conducting interface layer and to enhance the power conversion efficiency (PCE). According to the literature, $\mathrm{ZnO}$ has a high electron mobility, wide bandgap (3.37 eV), and large exciton binding energy of $60 \mathrm{meV}$ [8]. Magnesium $(\mathrm{Mg})$ is one of the metals that is used in many applications such as refractory materials and optical and heating apparatus $[9,10]$. Mg-doped $\mathrm{ZnO}$ material also has special properties to block the electron due to its wide bandgap [11, 12]. There are several methods to grow thin film on a substrate, such as molecular beam epitaxy, metal-organic chemical vapor deposition, plasma- 
enhanced chemical deposition, sputtering method, spray pyrolysis, atomic layer deposition, pulse laser deposition, electron beam evaporation, and sol-gel [13]. The sol-gel method has several advantages compared to the aforementioned methods such as simple, cheap, and efficient [14]. By using a sol-gel spin coating technique, several parameters like concentration of precursor solution, annealing temperature, and annealing time can be easily tuned in order to achieve the desired properties $[12,15]$.

In this work, the photoanodes of $\mathrm{Mg}$-doped $\mathrm{ZnO}$ thin films were prepared by a sol-gel spin coating method. To the best of our knowledge, the natural dye from the fruit extract of Rhodomyrtus tomentosa has not been reported yet as the dye sensitizer for DSSC. The effect of different annealing temperatures on structural and optical properties of $\mathrm{Mg}$-doped $\mathrm{ZnO}$ photoanodes as well as the efficiency of DSSC device was systematically investigated using necessary characterization tools. We find that the maximum efficiency of the DSSC device is $3.53 \%$ with $\mathrm{Mg}$-doped $\mathrm{ZnO}$ photoanode annealed at $500^{\circ} \mathrm{C}$.

\section{Experimental Section}

2.1. Synthesis of $\mathrm{Mg}$-Doped $\mathrm{ZnO}$ Thin Films. Mg-doped $\mathrm{ZnO}$ thin films were fabricated using a sol-gel spin coating technique. Typically, zinc acetate dihydrate and magnesium chloride (2wt.\%) were dissolved in isopropanol (35 mL) under continuous stirring. After $10 \mathrm{~min}, 1.7 \mathrm{~mL}$ diethanolamine was added slowly into the solution. After refluxing process at $90^{\circ} \mathrm{C}$ for about 2 hours, the gel was dropped on top of FTO glass and spun at $5000 \mathrm{rpm}$ for $60 \mathrm{~s}$. After the drying process, the samples were annealed at different temperatures of $400,450,500$, and $550^{\circ} \mathrm{C}$ for 5 hours.

2.2. Extraction of Natural Dyes. About 50 grams of Rhodomyrtus tomentosa fruit was ground using a mortar. After being moved into a beaker glass, $25 \mathrm{~mL}$ DI water, $21 \mathrm{~mL}$ ethanol, and $4 \mathrm{~mL}$ acetic acid were added and then stirred to form a homogeneous solution. The solution was then covered with aluminum foil to avoid photooxidation and socked at room temperature for $24 \mathrm{~h}$. Finally, the solid and liquid parts were separated using filter paper. The filtered solution of Rhodomyrtus tomentosa fruit extract was ready to be used as the sensitizer in DSSCs.

2.3. Fabrication of DSSC. Figure 1 illustrates the schematic fabrication of the DSSC device. First, the as-prepared Mgdoped $\mathrm{ZnO}$ thin film was used as the photoanode electrode. Natural dye sensitized from Rhodomyrtus tomentosa fruit extract was adsorbed on the top of $\mathrm{Mg}$-doped $\mathrm{ZnO}$ photoanode by immersing it into the extracted dye solution for several hours. After that, it was taken out and washed with ethanol to remove the unadsorbed dye and dried in the oven at $80^{\circ} \mathrm{C}$. The commercial platinum coated on the glass FTO was used as the counter electrode. The DSSCs were assembled by attaching the photoanode and the counter electrode using thermoplastic sealant surlyn as glue and separator and then heated at $80^{\circ} \mathrm{C}$ to let the surlyn perfectly attach to the electrodes. The electrolyte was injected through a tiny hole

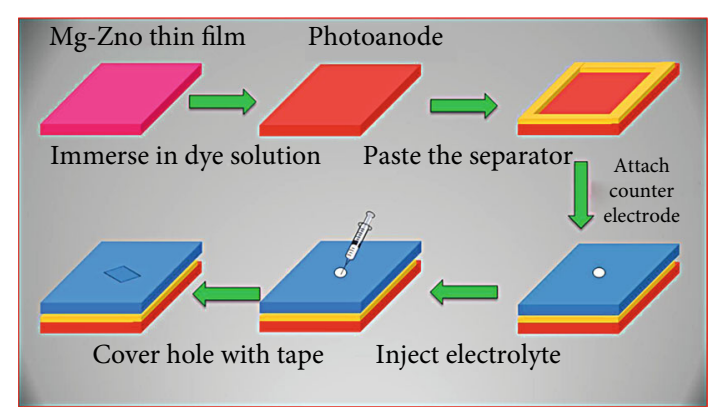

FIgURe 1: Schematic of the fabrication of DSSC using Mg-doped $\mathrm{ZnO}$ photoanode and fruit extract of Rhodomyrtus tomentosa.

that was drilled on the counter electrode. Finally, that hole was covered with transparent tape.

2.4. Characterization Tools. To observe the surface morphology of $\mathrm{Mg}$-doped $\mathrm{ZnO}$ thin films annealed at different temperatures, a scanning electron microscope (JEOL-6500) analysis was performed at an accelerating voltage of $15 \mathrm{kV}$. The X-ray diffraction (XRD) pattern of Mg-doped $\mathrm{ZnO}$ thin films was analyzed using an X-ray diffractometer (LabX XRD-6100, Shimadzu) with $\mathrm{Cu} \operatorname{K} \alpha(\lambda=1.54 \AA)$. The transmittance and absorbance spectra were recorded using a UV-Vis NIR spectrophotometer. The efficiency of the DSSC was measured using an I-V measurement (Keithley Source Measure Unit) system by irradiating a photoanode electrode with a LED and input power of $35 \mathrm{~mW} / \mathrm{cm}^{2}$. Several data such as open-circuit voltage $\left(V_{\mathrm{oc}}\right)$, short circuit current density $\left(J_{\mathrm{sc}}\right)$, maximum voltage $\left(V_{\max }\right)$, and maximum current $\left(J_{\max }\right)$ were recorded. Then, the fill factor $(\mathrm{FF})$ and efficiency $(\eta)$ were determined using equations (1) and (2), respectively.

$$
\begin{aligned}
\mathrm{FF} & =\frac{J_{\max } \times V_{\max }}{J_{\mathrm{sc}} \times V_{\mathrm{oc}}} \\
\mathrm{\eta} & =\mathrm{FF} \frac{J_{\mathrm{sc}} \times V_{\mathrm{oc}}}{P_{\text {in }}} \times 100 \% .
\end{aligned}
$$

\section{Results and Discussion}

3.1. Electron Microscope Analysis. The surface morphology of $\mathrm{Mg}$-doped $\mathrm{ZnO}$ with variation of annealing temperatures was investigated using a field-emission scanning electron microscope. With a magnification of $30 \mathrm{k}$ times, the top view images of $\mathrm{Mg}$-doped $\mathrm{ZnO}$ thin films can be clearly observed in Figure 2. The surface microstructure of $\mathrm{Mg}$-doped $\mathrm{ZnO}$ at different annealing temperatures shows nanoparticles with irregular shapes. It was clearly observed that by increasing the annealing temperature, the particle size was monotonically increased. Figure 2(d) shows the representative energy dispersive spectroscopy (EDS) spectra. The spectra exhibit five peaks to indicate the presence of zinc, oxygen, magnesium, platinum, and tin in the film. The appearance of platinum is contributed from the platinum coating before SEM analysis to improve the conductivity while tin comes from the substrate. The presence of a relatively low-intensity peak 


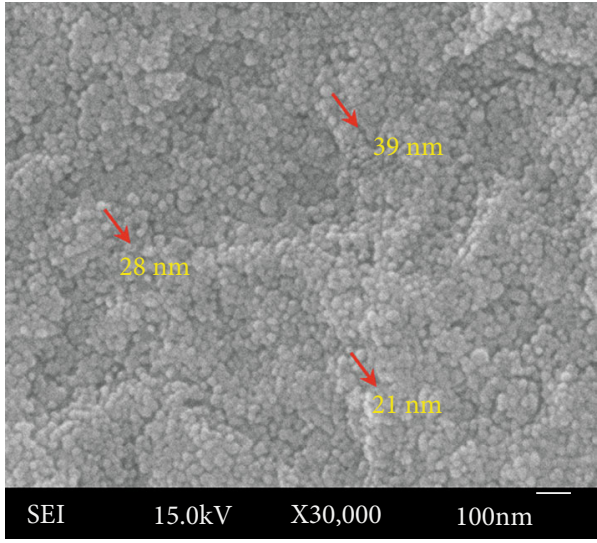

(a)

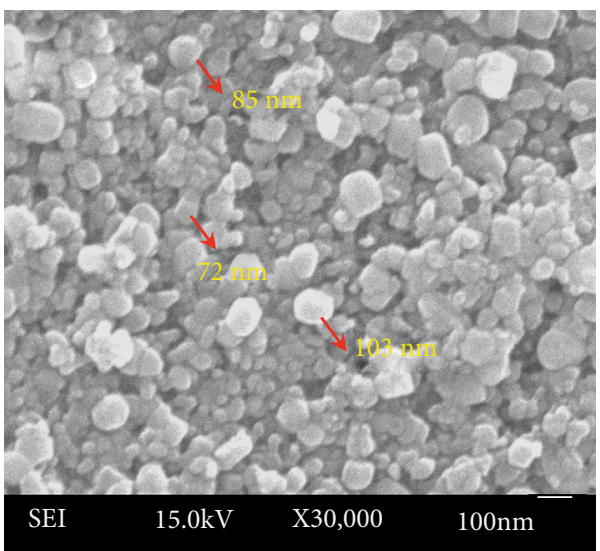

(c)

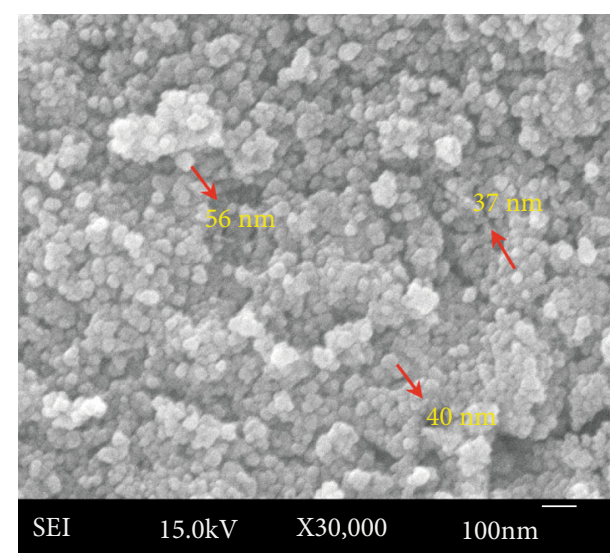

(b)

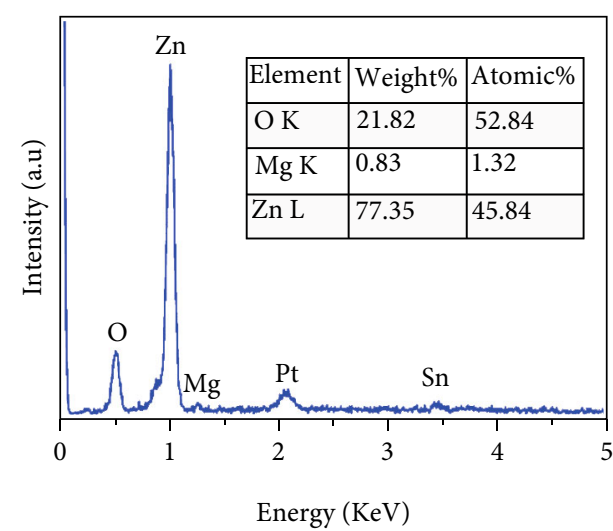

(d)

Figure 2: Scanning electron microscope images of Mg-doped $\mathrm{ZnO}$ with variation of annealing temperatures: (a) 400, (b) 500, (c) 550, and (d) representative EDS analysis.

for $\mathrm{Mg}$ compared to zinc and $\mathrm{O}$ peaks confirmed the successful $\mathrm{Mg}$ doping into $\mathrm{ZnO}$ host. Furthermore, the EDS quantitative result depicted in Figure 2(d) has shown that the weight and atomic percentage of $\mathrm{Mg}$ are about 0.83 and $1.32 \%$, respectively.

To calculate the particle size more precisely, further analysis was conducted using Image analysis. As shown in Figures 3(a)-3(c), the average particle sizes for Mg-doped $\mathrm{ZnO}$ thin films annealed at 400,500 , and $550^{\circ} \mathrm{C}$ are $30 \pm 5$, $53 \pm 9$, and $82 \pm 17 \mathrm{~nm}$, respectively. A larger particle size at a higher annealing temperature was reasonable. It could be explained due to a higher driving force from thermal energy that leads to a faster particle growth through Ostwald ripening mechanism. Our findings also well agree with some previous reports $[16,17]$.

3.2. XRD Analyses. The crystal properties of $\mathrm{Mg}$-doped $\mathrm{ZnO}$ were studied by the XRD technique. The results are shown in Figure 4. The XRD patterns are similar to a wurtzite crystal structure based on the standard card of JCPDF \#36-1451 ( $\mathrm{ZnO})$ [18]. Three peaks that located at $32.5^{\circ}, 35.3^{\circ}$, and $37.0^{\circ}$ for $2 \theta$ could be assigned as (100), (001), and (101) planes of $\mathrm{ZnO}$, respectively. The other weak peak at about $38.5^{\circ}$ might be contributed by impurity as reported in the previous work [19]. The intensity of peaks in Figure 4 grad- ually elevates as the temperature of annealing increases, which indicates an improvement in the crystallinity of $\mathrm{Mg}$ doped $\mathrm{ZnO}$ films.

Table 1 lists the summary of structural properties of $\mathrm{Mg}$ doped $\mathrm{ZnO}$ thin films at different annealing temperatures. The average crystallite size of $\mathrm{Mg}$-doped $\mathrm{ZnO}$ thin films was calculated at (101) plane using the Scherrer formula as shown in equation (3) [20]. Their crystallite size values are $20.60,21.23,16.83$, and $22.9 \mathrm{~nm}$ at the annealing temperature of $400,450,500$, and $550^{\circ} \mathrm{C}$, respectively. Next, the dislocation density $(\delta)$ of $\mathrm{Mg}$-doped $\mathrm{ZnO}$ was further determined by equation (4) [21]. The dislocation density of $\mathrm{Mg}$-doped $\mathrm{ZnO}$ annealed at $400,450,500$, and $550^{\circ} \mathrm{C}$ is $2.36 \times 10^{-3}, 2.22 \times 10^{-3}, 3.53 \times 10^{-3}$, and $1.89 \times 10^{-3} \mathrm{~nm}^{-2}$, respectively. $\mathrm{Mg}$-doped $\mathrm{ZnO}$ annealed at $500^{\circ} \mathrm{C}$ has the highest dislocation density compared to other samples. Macrostrain value that indicates the peak shift position was calculated according to equation (5) [22]. Based on the database, the (101) plane for $\mathrm{ZnO}$ is located at $36.25^{\circ}$ with an interplanar spacing of $2.4759 \AA$. However, the (101) plane for our $\mathrm{Mg}$-doped $\mathrm{ZnO}$ is found at about $37.00^{\circ}$ for $2 \theta$ with a calculated interplanar spacing of $2.4272 \AA$. The peak shifting of about $0.75^{\circ}$ for $2 \theta$ also indicates that $\mathrm{Mg}$ as a dopant has been successfully doped into $\mathrm{ZnO}$ host lattice [23]. The macrostrain value was similar for different temperatures 


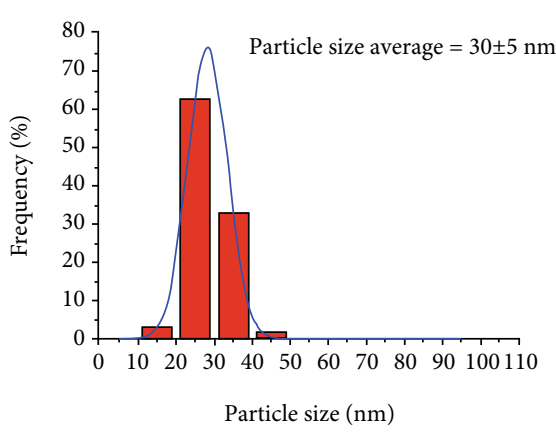

(a)

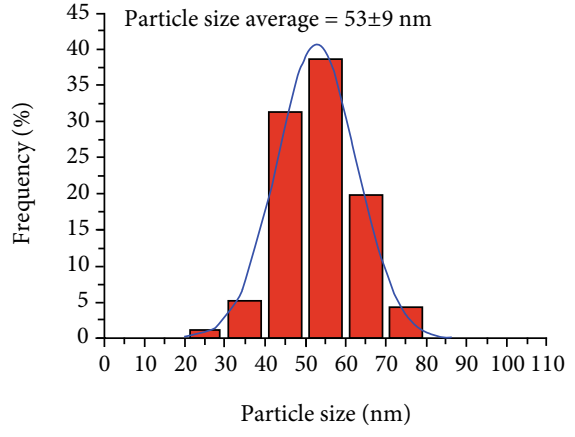

(b)

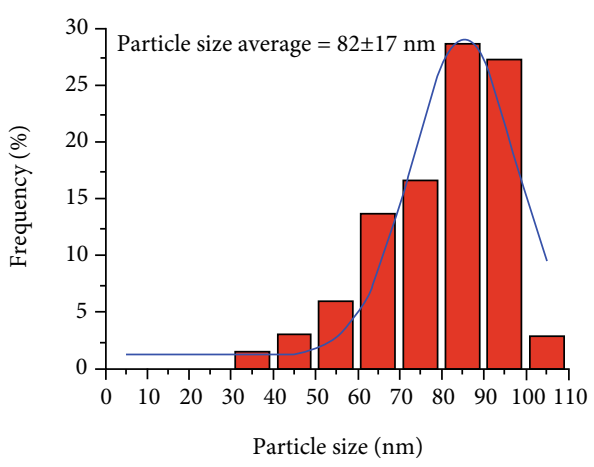

(c)

Figure 3: Particle size distribution of Mg-doped $\mathrm{ZnO}$ annealed at (a) 400, (b) 500, and (c) $550^{\circ} \mathrm{C}$.

with a value of $1.97 \times 10^{-2}$ because of their similarity in peak position. Based on the previous reports [24], the lattice parameters $a$ and $c$ of $\mathrm{Mg}$-doped $\mathrm{ZnO}$ were estimated to be about $3.172 \AA$ and $5.080 \AA$ using equations (6) and (7), respectively. The lattice parameter $a$ at the (100) plane did not significantly differ for different annealing temperatures because their peak position was located almost in the same diffraction angle. Similarly, the lattice parameter $c$ at the (002) plane is also very similar at different annealing temperatures, as listed in Table 1.

$$
D=\frac{0.9 \lambda}{\beta \cos \theta}
$$

where $D$ is the crystallite size $(\mathrm{nm}), \lambda$ is the wavelength $(\mathrm{nm}), \beta$ is the full half maximum, FWHM (rad), and $\theta$ is the Bragg angle $\left({ }^{\circ}\right)$.

$$
\begin{gathered}
\delta=\frac{1}{D^{2}}, \\
\langle e\rangle=\frac{d-d_{o}}{d_{o}},
\end{gathered}
$$

where $d_{o}$ is the interplanar spacing of pure $\mathrm{ZnO}$ without deformation while $d$ is the calculated interplanar spacing for Mg-doped $\mathrm{ZnO}$ at the (101) plane using the Bragg law.

$$
\begin{aligned}
& a=\frac{\lambda}{\sqrt{3} \sin \theta_{(100)}}, \\
& c=\frac{\lambda}{\sin \theta_{(002)}} .
\end{aligned}
$$

3.3. Optical Properties. To study the effect of different annealing temperatures on optical properties, the absorption and transmission spectra of $\mathrm{Mg}$-doped $\mathrm{ZnO}$ thin films are measured and presented in Figures 5 and 6, respectively. The absorption peaks of all $\mathrm{Mg}$-doped $\mathrm{ZnO}$ thin films are located at a wavelength of $350 \mathrm{~nm}$, which is at the UV region. As clearly shown in Figure 5, the absorption of $\mathrm{Mg}$-doped $\mathrm{ZnO}$ annealed at $400^{\circ} \mathrm{C}$ is quite low. However, after increasing the annealing temperature to $450^{\circ} \mathrm{C}$ and

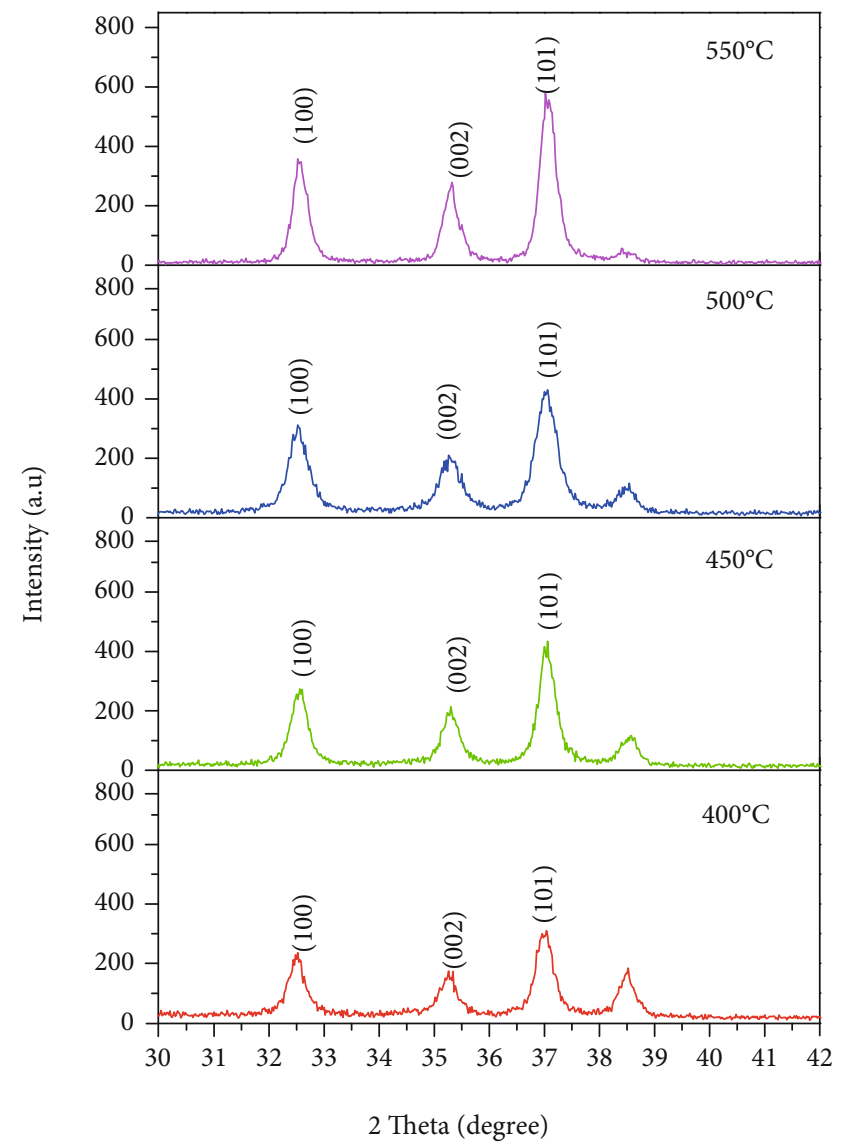

FIgURE 4: XRD pattern of Mg-doped $\mathrm{ZnO}$ thin films at different annealing temperatures.

$500^{\circ} \mathrm{C}$, the absorption sharply elevates. Further increasing the temperature of annealing to $550^{\circ} \mathrm{C}$ leads to a lower absorbance but is still higher than that at $400^{\circ} \mathrm{C}$. Figure 6 exhibits transmission spectra of $\mathrm{Mg}$-doped $\mathrm{ZnO}$ which also shows a similar trend to the absorption spectra in Figure 5. The thin films have transparency about $50-80 \%$ at visible light region.

The bandgap energy of $\mathrm{Mg}$-doped $\mathrm{ZnO}$ thin films was further derived based on the optical absorption data and plotted in Figure 7. As listed in Table 2, bandgap energy values are $3.20,3.24,3.30$, and $3.33 \mathrm{eV}$ for annealing at 
TABLE 1: Summary of crystal properties of FWHM, crystallite size, dislocation density, macrostrain values, and lattice parameters $(a$ and $c$ ) of $\mathrm{Mg}$-doped $\mathrm{ZnO}$ thin films at different annealing temperatures.

\begin{tabular}{lccccc}
\hline $\begin{array}{l}\text { Temperature } \\
\left({ }^{\circ} \mathrm{C}\right)\end{array}$ & $\begin{array}{c}\text { FWHM/ } \beta \\
(\mathrm{rad})\end{array}$ & $\begin{array}{c}\text { Crystallite } \\
\text { size }(\mathrm{nm})\end{array}$ & $\begin{array}{c}\text { Dislocation density } \\
\times 10^{-3}\left(\mathrm{~nm}^{-2}\right)\end{array}$ & $\begin{array}{c}\text { Macro strain values } \\
<e>\end{array}$ & $\begin{array}{c}\text { Lattice } \\
\text { parameters }(\AA) \\
a\end{array}$ \\
\hline 400 & 0.4065 & 20.60 & 2.36 & $1.97 \times 10^{-2}$ & 3.176 \\
450 & 0.3945 & 21.23 & 2.22 & $1.97 \times 10^{-2}$ & 3.082 \\
500 & 0.4976 & 16.83 & 3.53 & $1.97 \times 10^{-2}$ & 3.172 \\
550 & 0.3645 & 22.9 & 1.89 & $1.97 \times 10^{-2}$ & 3.080 \\
\hline
\end{tabular}

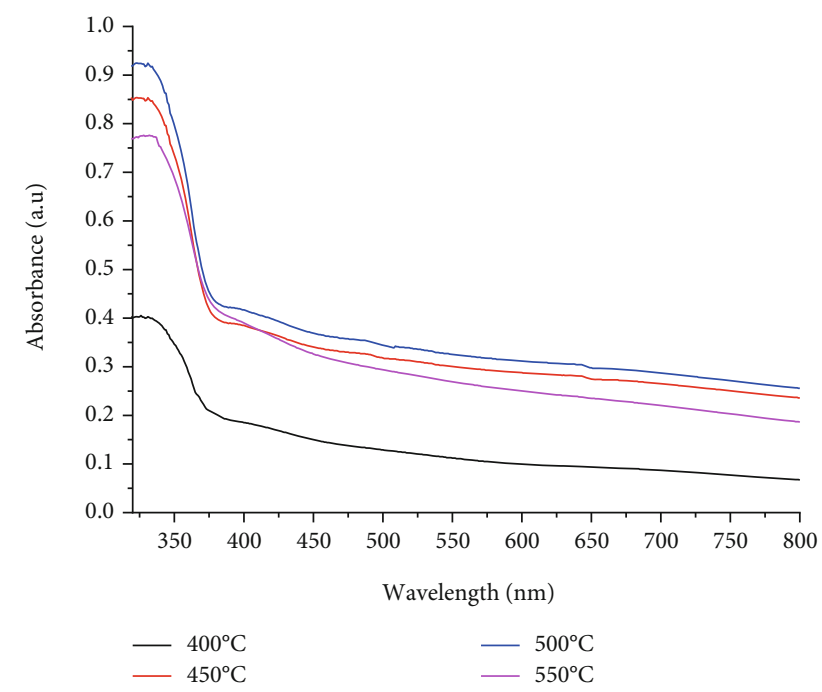

Figure 5: Absorbance spectra of Mg-doped $\mathrm{ZnO}$ thin films at different annealing temperatures.

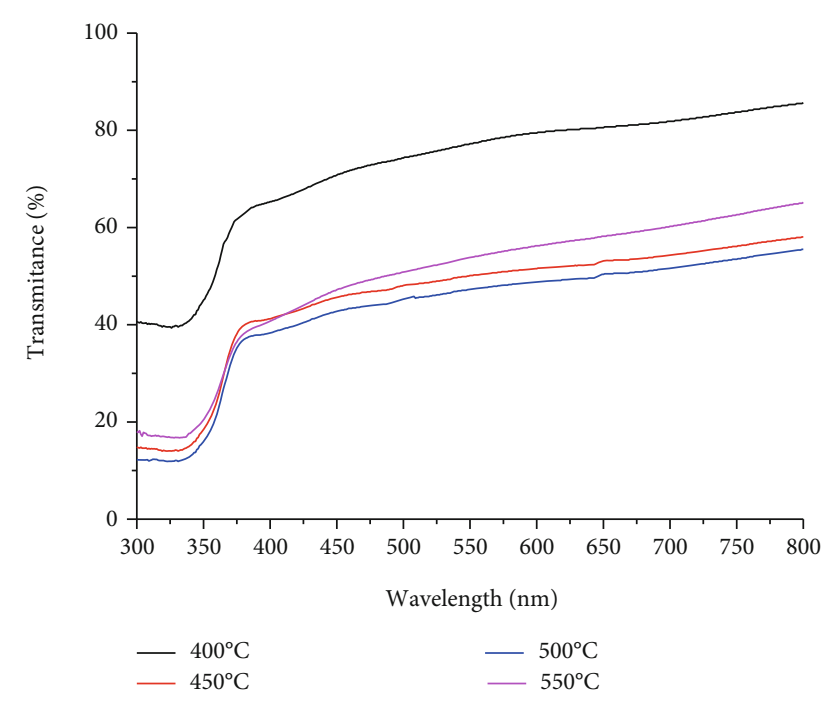

FIgure 6: Transmittance spectrum of Mg-doped $\mathrm{ZnO}$ thin films at different annealing temperatures.

$400,450,500$, and $550^{\circ} \mathrm{C}$, respectively. The slight increment of bandgap energy with increasing temperature might be due to the Burstein-Moss effect as reported in previous studies [25].

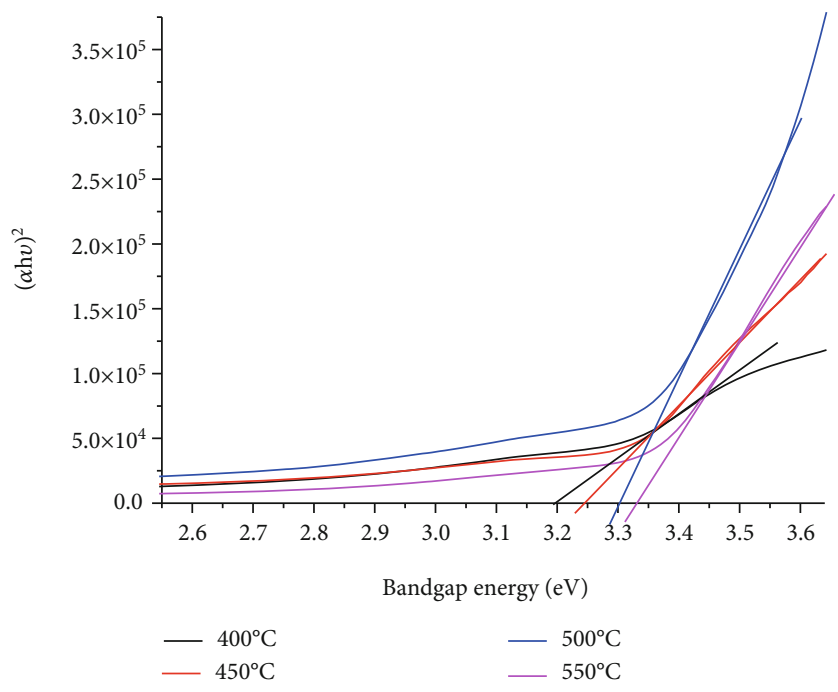

Figure 7: Tauc plot of $\mathrm{Mg}$-doped $\mathrm{ZnO}$ thin films at different annealing temperatures.

TABle 2: Bandgap energy of $\mathrm{Mg}$-doped $\mathrm{ZnO}$ thin film at different annealing temperatures.

\begin{tabular}{lc}
\hline Temperature $\left({ }^{\circ} \mathrm{C}\right)$ & Bandgap energy $(\mathrm{eV})$ \\
\hline 400 & 3.20 \\
450 & 3.24 \\
500 & 3.30 \\
550 & 3.33 \\
\hline
\end{tabular}

3.4. Absorbance of Rhodomyrtus tomentosa Dye Extract. The optical absorption spectrum of the extracted rose myrtle (Rhodomyrtus tomentosa) natural dye was measured using a UV-Vis spectrophotometer to investigate its sensitivity to light. As shown in Figure 8, the natural dye has a strong absorption at the visible-light region with an intense absorbance peak at a wavelength of $610 \mathrm{~nm}$. This property is very useful for DSSC to improve the light absorption ability. It is also well known that about $43 \%$ of the solar spectrum falls in the visible light range and only $4 \%$ is in the UV region [26]. The more light can be absorbed, the more electron-hole can be generated, which leads to a higher efficiency of a DSSC device.

3.5. Efficiency of DSSC. Figure 9 exhibits the $J-V$ characteristic curve of DSSC with Mg-doped $\mathrm{ZnO}$ as photoanode at 


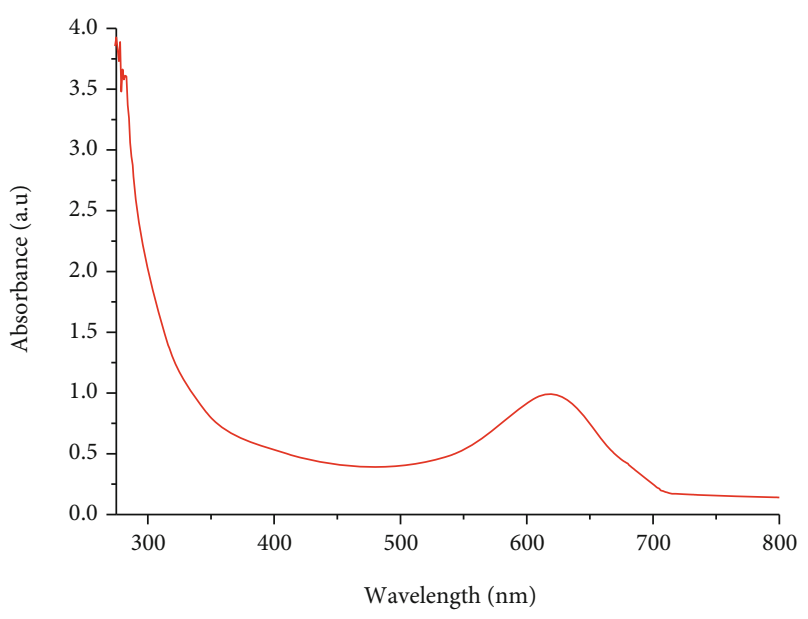

Figure 8: Absorbance spectrum of natural dye of extracted rose myrtle (Rhodomyrtus tomentosa).

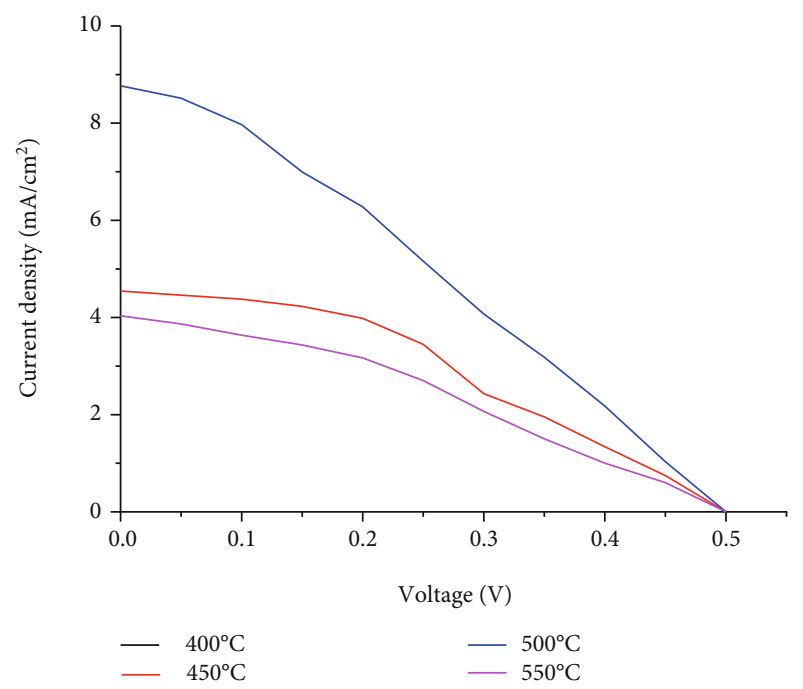

Figure 9: $J$ - $V$ characteristic curve of DSSC using Mg-doped $\mathrm{ZnO}$ as photoanode at different annealing temperatures.

TABle 3: Summary of electrical properties including open-circuit voltage, short-circuit current, fill factor, and efficiency of DSSC for different annealing temperatures.

\begin{tabular}{lccccc}
\hline $\begin{array}{l}\text { Temperature } \\
\left({ }^{\circ} \mathrm{C}\right)\end{array}$ & $\begin{array}{c}V_{\mathrm{oc}} \\
(\mathrm{V})\end{array}$ & $\begin{array}{c}J_{\mathrm{sc}}(\mathrm{mA} / \\
\left.\mathrm{cm}^{2}\right)\end{array}$ & $\begin{array}{c}P_{\max } \\
\left(\mathrm{mW} / \mathrm{cm}^{2}\right)\end{array}$ & $\begin{array}{c}\mathrm{FF} \\
(\%)\end{array}$ & $\begin{array}{c}\eta \\
(\%)\end{array}$ \\
\hline 400 & 0.5 & 3.83 & 0.61 & 31.70 & 1.66 \\
450 & 0.5 & 4.55 & 0.86 & 37.93 & 2.36 \\
500 & 0.5 & 8.77 & 1.29 & 29.42 & 3.53 \\
550 & 0.5 & 4.03 & 0.68 & 33.47 & 1.85 \\
\hline
\end{tabular}

different annealing temperatures and the fruit extract of Rhodomyrtus tomentosa as a natural dye sensitizer. Further, the photovoltaic properties of DSSC are listed in Table 3. The open-circuit voltage $\left(V_{o c}\right)$ at different annealing temperatures was similar with a value of $0.5 \mathrm{~V}$. In contrast, the short-circuit current $\left(J_{\mathrm{sc}}\right)$ was significantly different. The $J_{\text {sc }}$ values are $3.83,4.55,8.77$, and $4.03 \mathrm{~mA} / \mathrm{cm}^{2}$ at annealing temperatures of $400,450,500$, and $550^{\circ} \mathrm{C}$, respectively. The efficiency of the DSSC device annealed at $400^{\circ} \mathrm{C}$ was about $1.66 \%$. By increasing the annealing temperature to $450^{\circ} \mathrm{C}$, the efficiency also was increased to $2.36 \%$. Further increasing the annealing temperature to $500^{\circ} \mathrm{C}$, the efficiency of $3.53 \%$ can be achieved. However, the efficiency was observed to decline when the annealing temperature is $550^{\circ} \mathrm{C}$. Therefore, the optimum annealing temperature is $500^{\circ} \mathrm{C}$ with a maximum power conversion efficiency of $3.53 \%$. Based on the characterization results, the highest efficiency of $3.53 \%$ at $500^{\circ} \mathrm{C}$ could be contributed due to its highest optical absorption as revealed by UV-Vis analysis in Figure 5 .

\section{Conclusions}

We have successfully fabricated a dye-sensitized solar cell (DSSC) device using Mg-doped $\mathrm{ZnO}$ thin film as the photoanode and natural dye of rose myrtle (Rhodomyrtus tomentosa) as the dye sensitizer. The scanning electron microscope analysis revealed that the surface of Mg-doped $\mathrm{ZnO}$ thin film was particles with irregular shapes. It is found that increasing the annealing temperature led to a larger particle size and slightly increased bandgap energy. The natural rose myrtle dye sensitizer had a strong absorption at the visible light region. The maximum efficiency of the DSSC device was $3.53 \%$ at an annealing temperature of $500^{\circ} \mathrm{C}$. This work demonstrates that the annealing temperature of photoanode significantly affects the efficiency of the DSSC device.

\section{Data Availability}

The research data used to support the findings of this study are included in the article.

\section{Conflicts of Interest}

The authors declare that they have no conflicts of interest.

\section{Acknowledgments}

The authors would like to thank the Rector of Universitas Negeri Medan for supporting this research.

\section{References}

[1] J. Gong, J. Liang, and K. Sumathy, "Review on dye-sensitized solar cells (DSSCs): fundamental concepts and novel materials," Renewable and Sustainable Energy Reviews, vol. 16, no. 8, pp. 5848-5860, 2012.

[2] T.-L. Wu, T. H. Meen, S. M. Chao et al., "Application of $\mathrm{ZnO}$ micro rods on the composite photo-electrode of dye sensitized solar cells," Microsystem Technologies, vol. 24, no. 1, pp. 285289, 2018.

[3] R. Vittal and K.-C. Ho, "Zinc oxide based dye-sensitized solar cells: a review," Renewable and Sustainable Energy Reviews, vol. 70, pp. 920-935, 2017.

[4] E. T. Bekele, E. A. Zereffa, N. S. Gultom, D.-H. Kuo, B. A. Gonfa, and F. K. Sabir, "Biotemplated synthesis of titanium oxide nanoparticles in the presence of root extract of Kniphofia schemperi and its application for dye sensitized solar cells," 
International Journal of Photoenergy, vol. 2021, Article ID 6648325, 12 pages, 2021.

[5] U. Mehmood, S.-u. Rahman, K. Harrabi, I. A. Hussein, and B. V. S. Reddy, "Recent advances in dye sensitized solar cells," Advances in Materials Science and Engineering, vol. 2014, Article ID 974782, 12 pages, 2014.

[6] S. Datta, A. Dey, N. R. Singha, and S. Roy, "Enhanced performance of dye-sensitized solar cell with thermally stable natural dye-assisted $\mathrm{TiO}_{2} / \mathrm{MnO}_{2}$ bilayer-assembled photoanode," Materials for Renewable and Sustainable Energy, vol. 9, 2020.

[7] M. Ye, X. Wen, M. Wang et al., "Recent advances in dyesensitized solar cells: from photoanodes, sensitizers and electrolytes to counter electrodes," Materials Today, vol. 18, no. 3, pp. 155-162, 2015.

[8] S. Sasidharan, S. Soman, S. C. Pradhan et al., "Fine tuning of compact $\mathrm{ZnO}$ blocking layers for enhanced photovoltaic performance in $\mathrm{ZnO}$ based DSSCs: a detailed insight using $\beta$ recombination, EIS, OCVD and IMVS techniques," New Journal of Chemistry, vol. 41, no. 3, pp. 1007-1016, 2017.

[9] M. Rashad, H. O. Tekin, H. M. H. Zakaly, M. Pyshkina, S. A. M. Issa, and G. Susoy, "Physical and nuclear shielding properties of newly synthesized magnesium oxide and zinc oxide nanoparticles," Nuclear Engineering and Technology, vol. 52, no. 9, pp. 2078-2084, 2020.

[10] X. Fu, S. Jiao, Y. Jiang et al., "Large-scale growth of ultrathin low-dimensional perovskite nanosheets for high-detectivity photodetectors," ACS Applied Materials \& Interfaces, vol. 12, no. 2, pp. 2884-2891, 2020.

[11] D. Fang, C. Li, N. Wang, P. Li, and P. Yao, "Structural and optical properties of $\mathrm{Mg}$-doped $\mathrm{ZnO}$ thin films prepared by a modified Pechini method," Crystal Research and Technology, vol. 48, no. 5, pp. 265-272, 2013.

[12] F. Lekoui, S. Hassani, M. Ouchabane et al., "Elaboration and characterization of $\mathrm{Mg}$-doped $\mathrm{ZnO}$ thin films by thermal evaporation: annealing temperature effect," Brazilian Journal of Physics, vol. 51, no. 3, pp. 544-552, 2021.

[13] A. Jilani, M. Abdel-wahab, and A. Hammad, Advance deposition techniques for thin film and coating, 2017.

[14] F. Aslan, A. Tumbul, A. Göktaş, R. Budakoğlu, and İ. H. Mutlu, "Growth of $\mathrm{ZnO}$ nanorod arrays by one-step sol-gel process," Journal of Sol-Gel Science and Technology, vol. 80, no. 2, pp. 389-395, 2016.

[15] M. N. H. Mia, M. F. Pervez, M. K. Hossain et al., "Influence of $\mathrm{Mg}$ content on tailoring optical bandgap of $\mathrm{Mg}$-doped $\mathrm{ZnO}$ thin film prepared by sol-gel method," Results in Physics, vol. 7, pp. 2683-2691, 2017.

[16] M. Arif, A. Sanger, P. M. Vilarinho, and A. Singh, "Effect of annealing temperature on structural and optical properties of sol-gel-derived $\mathrm{ZnO}$ thin films," Journal of Electronic Materials, vol. 47, no. 7, pp. 3678-3684, 2018.

[17] T.-H. Chen, M. W. Wang, C. L. Yang, and Y. S. Huang, "Effects of different annealing temperature on the optoelectrical properties of MGZO thin films prepared by co-sputtering method," Microsystem Technologies, vol. 25, no. 5, pp. 2109-2115, 2019.

[18] N. S. Gultom, H. Abdullah, and D.-H. Kuo, "Phase transformation of bimetal zinc nickel oxide to oxysulfide photocatalyst with its exceptional performance to evolve hydrogen," Applied Catalysis B: Environmental, vol. 272, p. 118985, 2020.

[19] J. L. Konne and B. O. Christopher, "Sol-Gel Syntheses of Zinc Oxide and Hydrogenated Zinc Oxide (ZnO:H) Phases," Jour- nal of Nanotechnology, vol. 2017, Article ID 5219850, 8 pages, 2017.

[20] N. S. Gultom, H. Abdullah, and D.-H. Kuo, "Facile synthesis of cobalt-doped $(\mathrm{Zn}, \mathrm{Ni})(\mathrm{O}, \mathrm{S})$ as an efficient photocatalyst for hydrogen production," Journal of the Energy Institute, vol. 92, no. 5, pp. 1428-1439, 2019.

[21] H. Ertap and M. Karabulut, "Structural and electrical properties of boron doped InSe single crystals," Materials Research Express, vol. 6, no. 3, 2019.

[22] E. M. Al-Khalqi, M. A. A. Hamid, N. H. Al-Hardan, and L. K. Keng, "Highly sensitive magnesium-doped $\mathrm{ZnO}$ nanorod $\mathrm{pH}$ sensors based on electrolyte-insulator-semiconductor (EIS) Sensors," Sensors, vol. 21, no. 6, p. 2110, 2021.

[23] M. A. Zeleke, D. H. Kuo, K. E. Ahmed, and N. S. Gultom, "Facile synthesis of bimetallic $(\mathrm{In}, \mathrm{Ga})_{2}(\mathrm{O}, \mathrm{S})_{3}$ oxy-sulfide nanoflower and its enhanced photocatalytic activity for reduction of Cr(VI)," Journal of Colloid and Interface Science, vol. 530, pp. 567-578, 2018.

[24] S. Kurtaran, "Al doped $\mathrm{ZnO}$ thin films obtained by spray pyrolysis technique: influence of different annealing time," Optical Materials, vol. 114, p. 110908, 2021.

[25] A. Goktas, A. Tumbul, Z. Aba, and M. Durgun, "Mg doping levels and annealing temperature induced structural, optical and electrical properties of highly c-axis oriented $\mathrm{ZnO}: \mathrm{Mg}$ thin films and Al/ZnO:Mg/p-Si/Al heterojunction diode," Thin Solid Films, vol. 680, pp. 20-30, 2019.

[26] N. S. Gultom, H. Abdullah, J. C. Xie, and D. H. Kuo, “Transforming $\mathrm{Zn}(\mathrm{O}, \mathrm{S})$ from UV to visible-light-driven catalyst with improved hydrogen production rate: effect of indium and heterojunction," Journal of Alloys and Compounds, vol. 869, p. 159316, 2021. 